\title{
Flexural behaviour of basalt fibred concrete slabs made with basalt fibre reinforced polymer rebars
}

\author{
$M d$ Hasham $^{1 *}$, Srinivasa Reddy $\mathrm{V}^{2}, M V$ Seshagiri Rao ${ }^{3}$, and $S$ Shrihari ${ }^{4}$ \\ ${ }^{1}$ M. Tech (Structural Engineering), Department of Civil Engineering, GRIET, Hyderabad, India. \\ ${ }^{2}$ Professor of Civil Engineering, GRIET, Hyderabad, India. \\ ${ }^{3}$ Professor of Civil Engineering, CVR College of Engineering, Hyderabad, Telangana. \\ ${ }^{4}$ Professor of Civil Engineering, VJIT, Hyderabad, India.
}

\begin{abstract}
In this paper, the flexural behaviour of M30 grade basalt fibred concrete slabs made with basalt fibre reinforced polymer rebars are studied and compared with slabs made with steel rebars. The optimum percentage of basalt is $0.3 \%$ for $50 \mathrm{~mm}$ length basalt fibres. Due to high particle packing density in concrete made with basalt fibre micro cracks are prevented due to enhanced fatigue and stress dissipation capacity. Addition of basalt fibres to enhances the energy absorbtion capacity or toughness thereby enhancing the resistance to local damage and spalling. Addition of basalt fibres controlled the crack growth and crack width. Load at first crack of M30 grade basalt fibred concrete slabs made with basalt fibre reinforced polymer rebars is more than M30 grade conventional concrete slabs made with steel rebars because the with addition of basalt and BFRP bars will make either the interfacial transition zone (ITZ) strong or due to bond strength of concrete slabs made with basalt fibre reinforced polymer rebars. The ultimate strength in M30 grade basalt fibred concrete slabs made with basalt fibre reinforced polymer rebars is more than conventional concrete slabs made with steel rebars. Deflection at the centre of M30 grade basalt fibred concrete slabs made with basalt fibre reinforced polymer rebars is almost double than the conventional concrete slabs made with steel rebars. Toughness indices evaluated for M30 grade basalt fibred concrete slabs made with basalt fibre reinforced polymer rebars indicates that basalt fibre and BFRP bars will enhance the energy absorbtion capacity of slabs.
\end{abstract}

\section{Introduction}

In the current study, M30 grade basalt fibred concrete slabs made with basalt fibre reinforced polymer rebars and with steel rebars of size $1200 \mathrm{~mm} * 1200 \mathrm{~mm} * 100$ $\mathrm{mm}$ are casted and studied for flexural characteristics such as first crack, ultimate load carrying capacity and deflection at centre.

\section{Methodology}

In the present study, basalt fibres of length $50 \mathrm{~mm}$ and dosage of $0.3 \%$ fibre volume of the concrete are adopted based on the studies conducted by the authors. The quantities per $\mathrm{m}^{3}$ of concrete for M30 grade concrete adopted are-

Grade of the concrete - M30
Cement- $366 \mathrm{~kg} / \mathrm{m}^{3}$

Fine aggregate- $689.1 \mathrm{~kg} / \mathrm{m}^{3}$

Coarse aggregate- $1139.2 \mathrm{~kg} / \mathrm{m}^{3}$

Water- $187 \mathrm{l} / \mathrm{m}^{3}$

Mix proportion is 1: 1.82: 3.09

\section{Flexural behaviour concrete slabs}

In the present study, flexural behaviour of M30 grade basalt fibred concrete slabs made with basalt fibre reinforced polymer rebars. Considering the limitations of the test facilities available the laboratory and handling issues of the test specimens, the size of the concrete slab specimens was fixed as $1200 * 1200 * 100 \mathrm{~mm}$ with nominal reinforcement of $8 \mathrm{~mm}$ diameter HYSD bars $200 \mathrm{~mm} \mathrm{C/C}$ both ways were casted and tested to determine the flexural characteristics of M30 grade basalt fibred concrete

\footnotetext{
*Corresponding author: hashamis61@gmail.com
} 
slabs made with basalt fibre reinforced polymer rebars.

The slabs were tested in a loading frame which consists of supporting main beams and cross beams at the bottom. Load is applied through a hydraulic jack of $100 \mathrm{~T}$ at the centre as marked. Proving ring with dial gauges was used to measure the load applied. The corresponding deflections at mid-point were measured using $50 \mathrm{~mm}$ dial gauges with least count of $0.01 \mathrm{~mm}$. Crack widths were measured using crack detection microscope of least count $0.02 \mathrm{~mm}$. Schematic diagram of the loading system and test set up is shown in Fig.3.

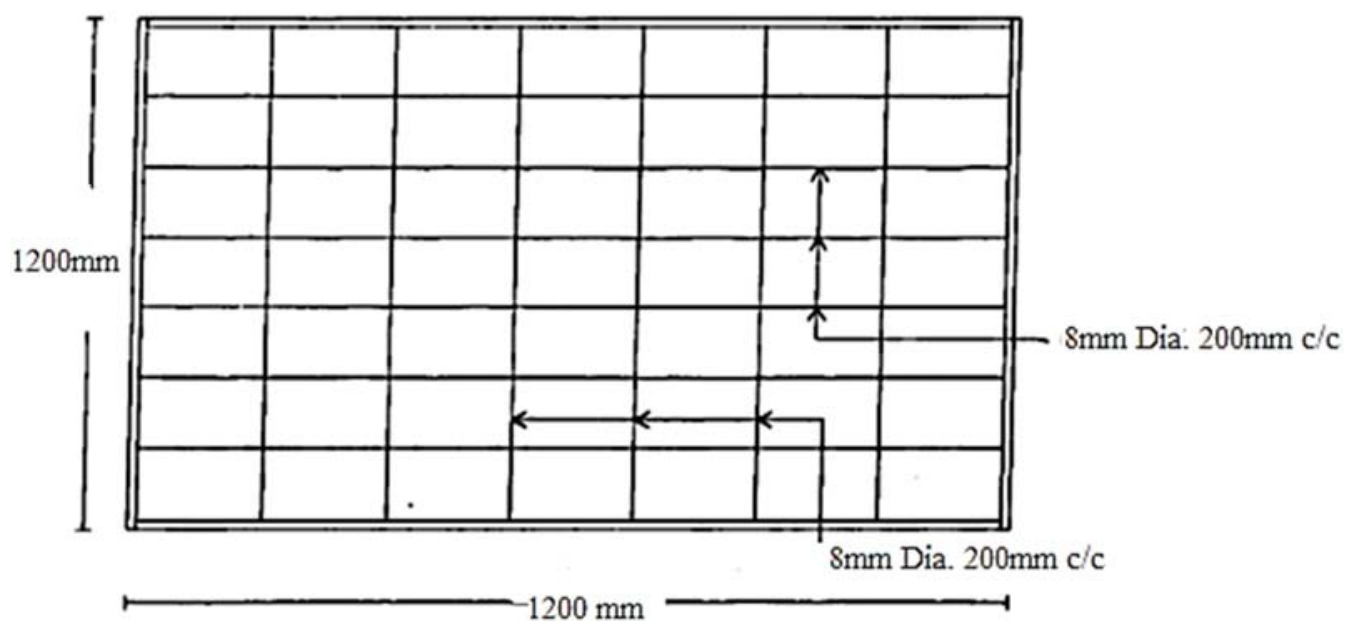

Fig.1. Reinforcement mesh

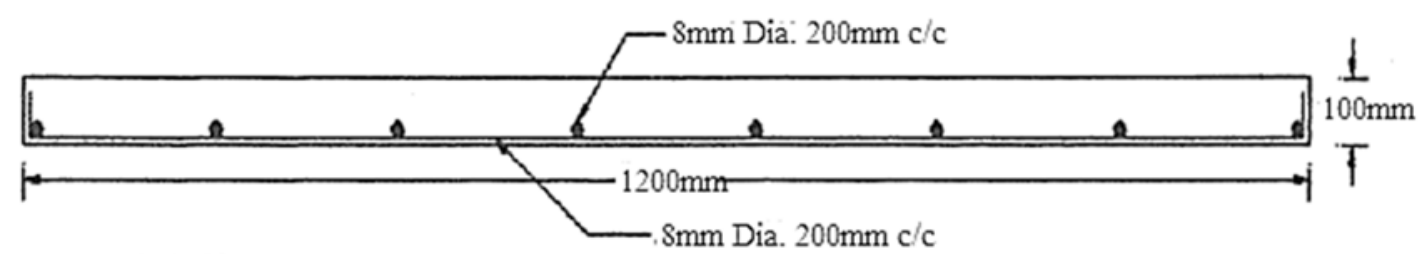

Fig.2. Cross-section of slab specimen

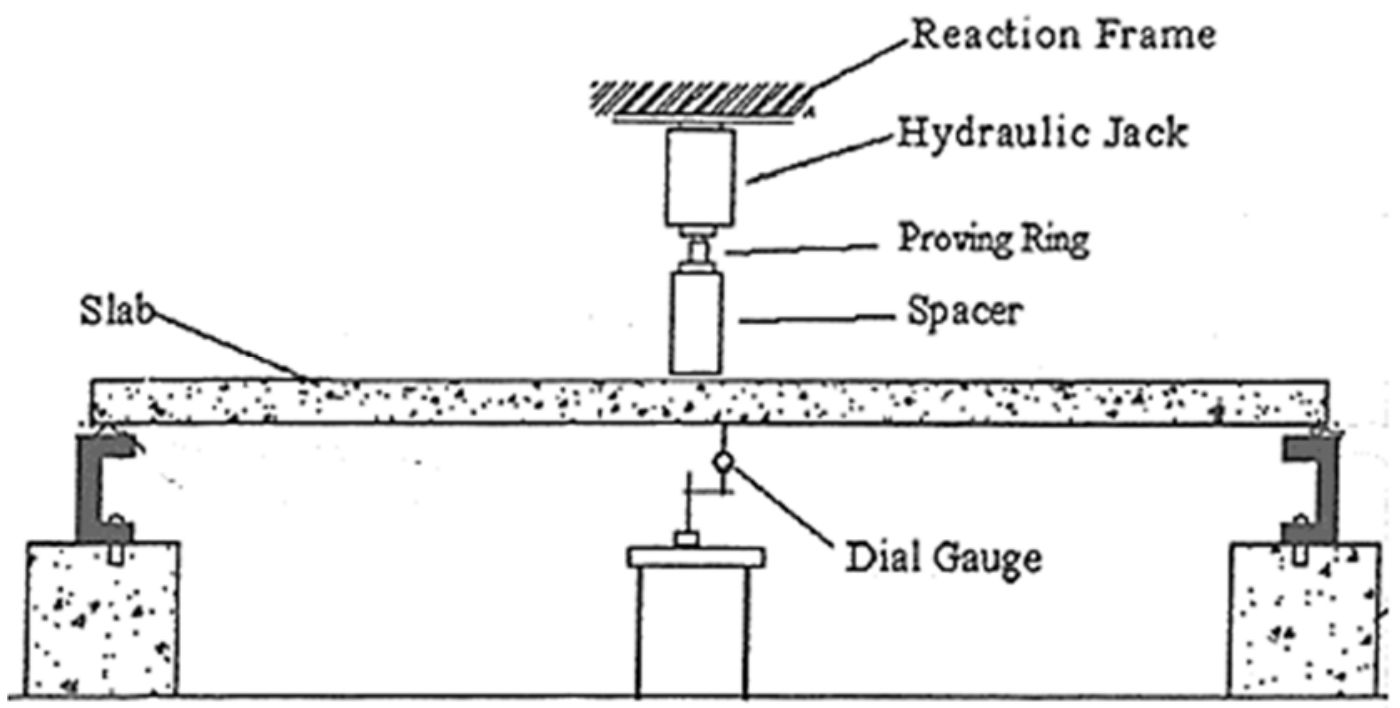

Fig.3. Schematic diagram of the loading system test setup 

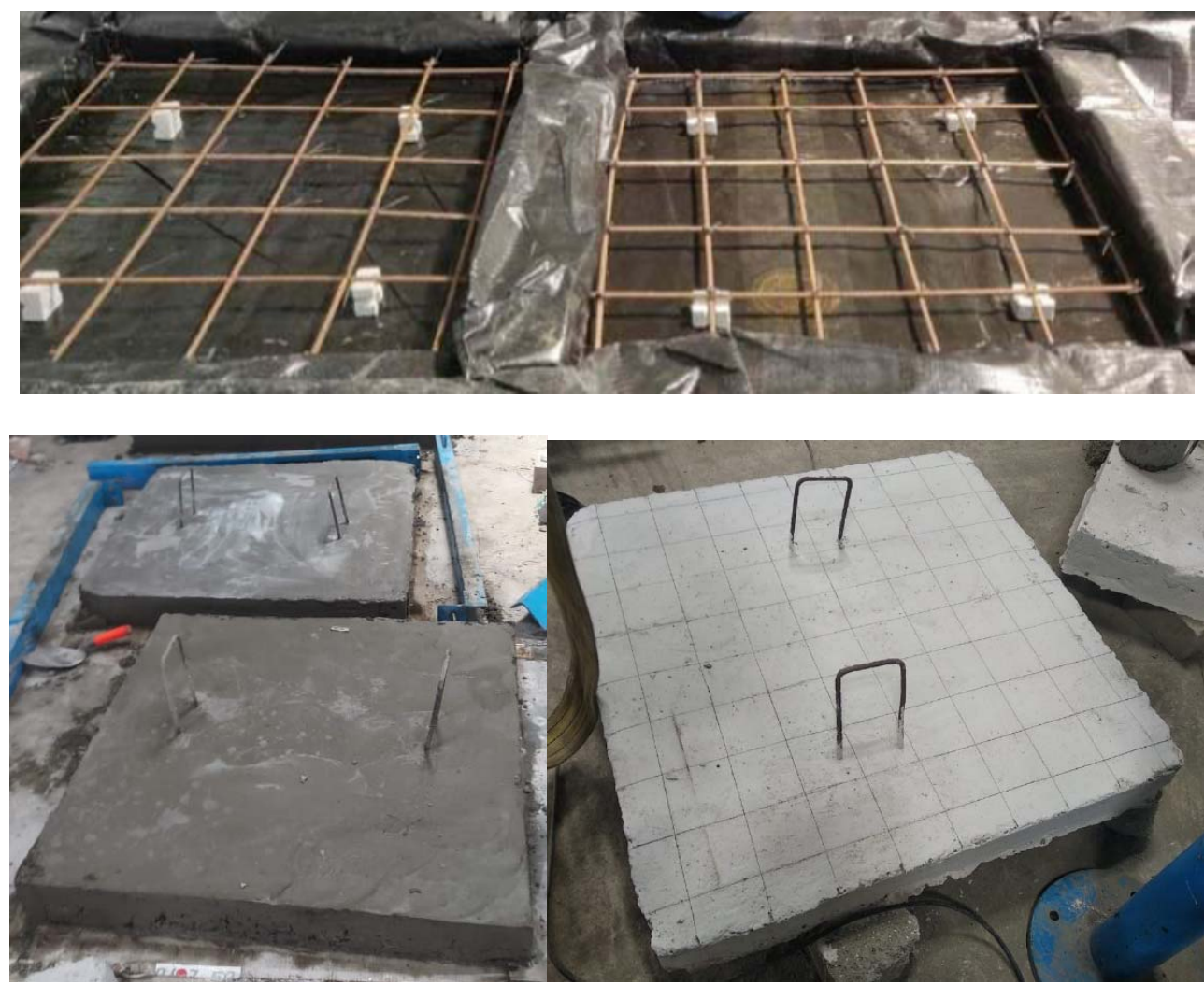

Fig.4. Casting of slabs

Load was applied to the slab by operating the hydraulic jack. The following observations were made:

1. Deflection at mid-point

2. First crack load and location of first crack

3. Propagation of crack

4. Ultimate load at failure

5. Mode of failure

The first crack load was taken as the load corresponding to the first visible crack. The load at which the deflections increased without any significant increase in load was taken as the ultimate load. The readings beyond ultimate load could not be noted since the test set up started losing stability due to excessive deflection. The test set up is so that all the four edges are simply supported.

\section{Toughness Index}

Toughness Index is measured from load deflection curves of slabs. Toughness can be quantified using the area under the curve or standardized with respect to the area under the curve up to the first crack. The Toughness (TI) is computed as ratio defined by the following equation.
Toughness Index TI

Area under load deflection curve up to ultimate load $=\frac{\text { Area under load deflection curve up to First crack }}{}$

Toughness can be quantified using the area under the curve or Standardized with respect to the area under the curve up to the first crack.

M30 grade basalt fibred concrete slabs made with basalt fibre reinforced polymer rebars of size 1200 $\mathrm{mm} * 1200 \mathrm{~mm} * 100 \mathrm{~mm}$ are casted. Flexural characteristics such as first crack, ultimate load carrying capacity and deflection at centre are tabulated.

Table 1. Designation of slabs

\begin{tabular}{|c|c|c|}
\hline $\begin{array}{c}\text { Designation } \\
\text { of Slab }\end{array}$ & $\begin{array}{c}\text { Type of } \\
\text { Fibre }\end{array}$ & $\begin{array}{c}\text { Type of } \\
\text { rebar }\end{array}$ \\
\hline Slab 1 & No Fibre & Steel \\
\hline Slab 2 & Basalt Fibre & Steel \\
\hline Slab 3 & No Fibre & BFRP \\
\hline Slab 4 & Basalt Fibre & BFRP \\
\hline
\end{tabular}




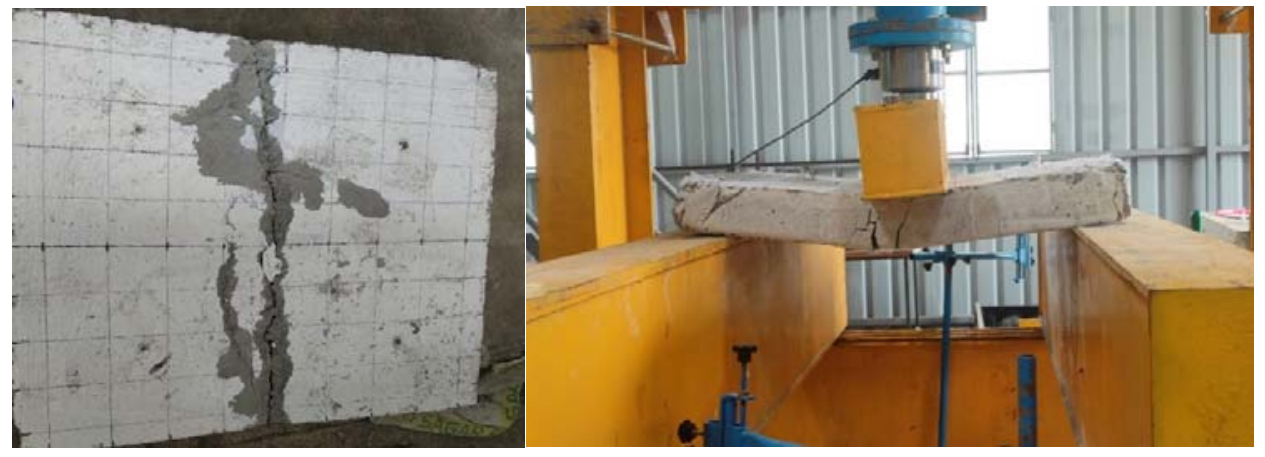

Fig.5. Testing of slab specimens

\section{Load - deflection relations}

Table 2. Load deflections of M30 grade reinforced concrete slabs made with BFRP and steel rebars

\begin{tabular}{|c|c|c|c|c|c|c|c|}
\hline \multicolumn{2}{|c|}{ No Fibre+ Steel rebars } & \multicolumn{2}{|c|}{ Basalt Fibre + Steel rebars } & \multicolumn{2}{|c|}{ No Fibre+ BFRP rebars } & \multicolumn{2}{|c|}{ Basalt Fibre+ BFRP rebars } \\
\hline 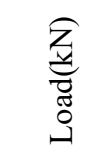 & 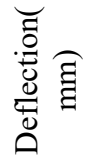 & 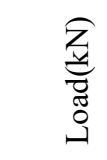 & 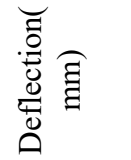 & 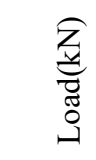 & 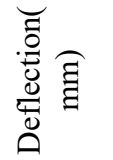 & 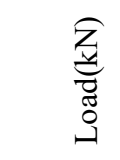 & 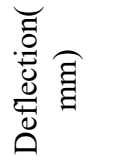 \\
\hline 0 & 0.00 & 0 & 0.00 & 0 & 0.00 & 0 & 0.00 \\
\hline 10 & 0.85 & 10 & 0.40 & 20 & 0.80 & 10 & 0.25 \\
\hline 20 & 1.50 & 20 & 1.00 & 30 & 1.50 & 20 & 0.90 \\
\hline 30 & 2.50 & 30 & 1.50 & 40 & 3.00 & 30 & 1.70 \\
\hline 40 & 3.80 & 40 & 2.80 & 50 & 4.10 & 40 & 2.20 \\
\hline 50 & 4.95 & 50 & 4.50 & 60 & 5.00 & 50 & 3.25 \\
\hline 60 & 6.00 & 60 & 5.50 & 70 & 5.80 & 60 & 4.00 \\
\hline 70 & 7.40 & 70 & 6.50 & 80 & 7.20 & 70 & 5.20 \\
\hline 80 & 8.50 & 80 & 8.00 & 90 & 8.50 & 80 & 6.50 \\
\hline 90 & 10.30 & 90 & 9.50 & 100 & 10.25 & 90 & 7.90 \\
\hline 100 & 11.90 & 100 & 11.25 & 110 & 13.00 & 100 & 9.85 \\
\hline 110 & 13.50 & 110 & 13.50 & 120 & 17.00 & 110 & 12.40 \\
\hline 120 & 15.00 & 120 & 16.00 & 130 & 18.96 & 120 & 18.00 \\
\hline 125 & 16.40 & 125 & 16.80 & & & 135 & 20.15 \\
\hline
\end{tabular}




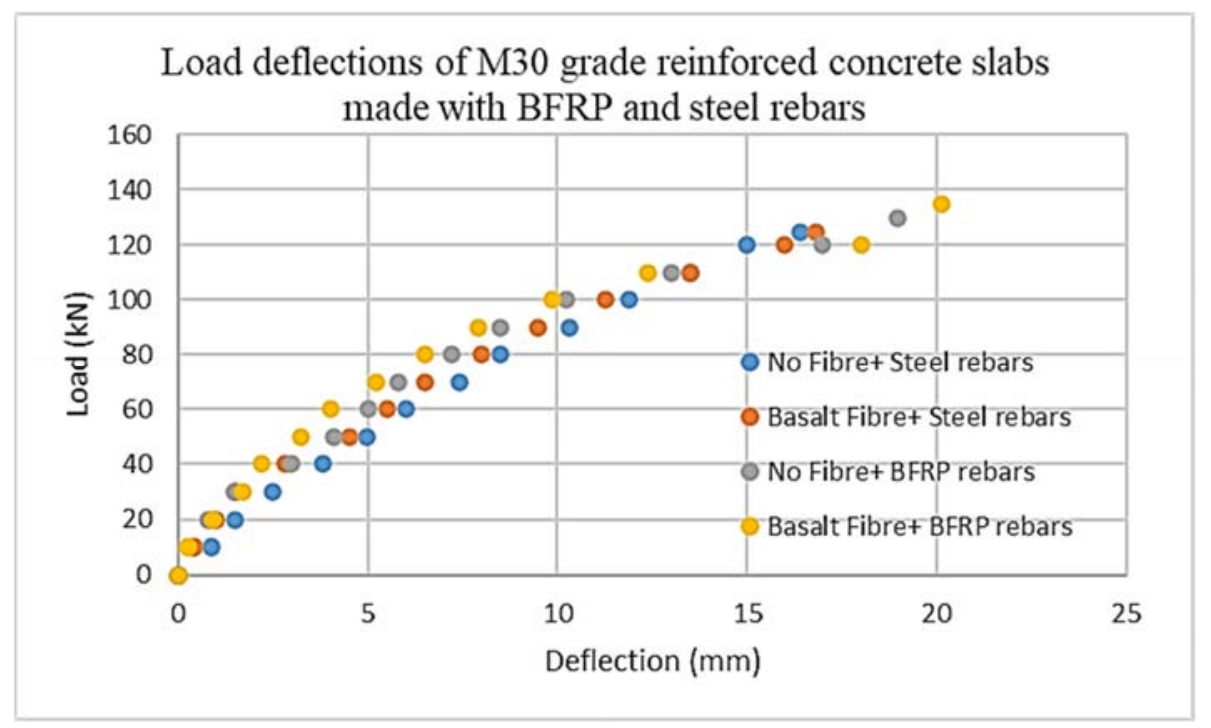

Fig.6. Load deflections of M30 grade reinforced concrete slabs

Table 3. Flexural characteristics of M30 grade reinforced concrete slabs made with steel and BFRP rebars

\begin{tabular}{|c|c|c|c|c|c|}
\hline \multirow{2}{*}{$\begin{array}{c}\text { Slab } \\
\text { Designation }\end{array}$} & \multirow[b]{2}{*}{ Type of Fibre } & \multirow[b]{2}{*}{ Type of rebar } & \multicolumn{3}{|c|}{ M30 Grade Concrete Slab } \\
\hline & & & $\begin{array}{l}\text { Load at first crack } \\
\text { occurrence }(\mathrm{kN})\end{array}$ & $\begin{array}{l}\text { Load at } \\
\text { failure } \\
(\mathrm{kN})\end{array}$ & $\begin{array}{l}\text { Mid-deflection } \\
(\mathrm{mm})\end{array}$ \\
\hline Slab 1 & No Fibre & Steel & 80 & 125 & 16.40 \\
\hline Slab 2 & Basalt Fibre & Steel & 60 & 125 & 16.8 \\
\hline Slab 3 & No Fibre & BFRP & 70 & 130 & 18.96 \\
\hline Slab 4 & Basalt Fibre & BFRP & 70 & 135 & 20.15 \\
\hline
\end{tabular}

Table 4. Toughness Index of M30 grade concrete slabs

\begin{tabular}{|c|c|c|c|}
\hline Designation of Slab & Type of Fibre & Type of rebar & $\begin{array}{c}\text { Toughness } \\
\text { Index }\end{array}$ \\
\hline Slab 1 & No Fibre & Steel & 3.01 \\
\hline Slab 2 & Basalt Fibre & Steel & 6.36 \\
\hline Slab 3 & No Fibre & BFRP & 6.47 \\
\hline Slab 4 & Basalt Fibre & BFRP & 7.47 \\
\hline
\end{tabular}

The toughness indices of M30 grade basalt fibred concrete slabs made with basalt fibre reinforced polymer rebars are presented in Table 4.

It can be seen that fibre addition delays crack initiation. Load-deflection curve was linear up to first crack and non-linear in post cracking stage. On further loading this crack propagated and more number of finer cracks appeared. After subsequent load increment this propagation of crack deviated from initial path and continued to grow and fork to join the corners so as to form a failure mechanism. Meanwhile a number of smaller cracks developed and they were interconnected to each other. Failure of slabs occurred due to widening of cracks along yield lines. The rate of increase in crack width was observed higher in the case of slabs without fibre. Cracks developed in fibre reinforced slabs were closely spaced and the crack width measure-d was found to be smaller than the cracks observed in slab without fibre at all load levels. Crack pattern for slabs with different fibre content are recorded. The load was increased at regular intervals and the load at which the deflection increased tremendously without increase in load was taken as the ultimate load.

\section{Discussions}

Concrete slab specimens of M30 grades were casted to study the flexural properties of M30 grade basalt 
fibred concrete slabs made with basalt fibre reinforced polymer (BFRP) rebars. From the load -deflection plots, flexural characteristics such as load at first crack, ultimate flexural strength and deflection at the centre are evaluated. From these results the following observations are made:

1. Load at first crack of M30 grade basalt fibred concrete slabs made with basalt fibre reinforced polymer rebars is more than M30 grade conventional concrete slabs made with steel rebars because the with addition of basalt and BFRP bars will make either the interfacial transition zone (ITZ) strong or due to bond strength of concrete slabs made with basalt fibre reinforced polymer rebars.

2. The ultimate strength in M30 grade basalt fibred concrete slabs made with basalt fibre reinforced polymer rebars is more than conventional concrete slabs made with steel rebars.

3. Deflection at the centre of M30 grade basalt fibred concrete slabs made with basalt fibre reinforced polymer rebars is almost double than the conventional concrete slabs made with steel rebars. Deflection at the centre of M30 grade basalt fibred concrete slabs made with basalt fibre reinforced polymer rebars is almost $80 \%$ more than the conventional concrete slabs made with steel rebars.

4. Toughness indices evaluated for M30 grade basalt fibred concrete slabs made with basalt fibre reinforced polymer rebars indicates that basalt fibre and BFRP bars will enhance the energy absorbtion capacity of slabs. Toughness index of M30 grade basalt fibred concrete slabs made with basalt fibre reinforced polymer rebars is 7.47 where as in conventional concrete slabs made with steel rebars its value is 6.36. So M30 grade basalt fibred concrete slabs made with basalt fibre reinforced polymer rebars increases the energy absorbtion capacity by 1.11 times that of conventional concrete slabs made with steel rebars.

\section{Conclusions}

Based on the experimental investigations and the corresponding test results to understand the flexural behaviour of M30 grade basalt fibred concrete slabs made with basalt fibre reinforced polymer rebars, conclusions are drawn.

1. The optimum percentage of basalt is $0.3 \%$ for $50 \mathrm{~mm}$ length basalt fibres as obtained from previous studies made by the author.

2. Due to high particle packing density in concrete made with basalt fibre micro cracks are prevented due to enhanced fatigue and stress dissipation capacity.
3. Addition of basalt fibres to enhances the energy absorbtion capacity or toughness thereby enhancing the resistance to local damage and spalling. Addition of basalt fibres controlled the crack growth and crack width.

4. Load at first crack of M30 grade basalt fibred concrete slabs made with basalt fibre reinforced polymer rebars is more than M30 grade conventional concrete slabs made with steel rebars because the with addition of basalt and BFRP bars will make either the interfacial transition zone (ITZ) strong or due to bond strength of concrete slabs made with basalt fibre reinforced polymer rebars. The ultimate strength in M30 grade basalt fibred concrete slabs made with basalt fibre reinforced polymer rebars is more than conventional concrete slabs made with steel rebars. Deflection at the centre of M30 grade basalt fibred concrete slabs made with basalt fibre reinforced polymer rebars is almost double than the conventional concrete slabs made with steel rebars.

5. Toughness indices evaluated for M30 grade basalt fibred concrete slabs made with basalt fibre reinforced polymer rebars indicates that basalt fibre and BFRP bars will enhance the energy absorbtion capacity of slabs.

So it can be concluded that the use of basalt fibres and BFRP bars in the concrete enhances its mechanical properties and their application in reinforced concrete elements improves the flexural characteristics of concrete elements significantly.

\section{References}

1. T.Srinivas and M. Abinay Raj, Int. J. of Eng.and Adv. Tech. (IJEAT), ISSN: 2249 - 8958, Volume-8 Issue-6 (2019)

2. T.srinivas and P. Manoj Anand, Int. J. of Innov. Tech. and Explor. Eng.g (IJITEE), ISSN: 22783075, Volume-8 Issue-12 (2019)

3. T.Srinivas and G. Sukesh Reddy, Int. J. of Eng.and Adv. Tech. (IJEAT), ISSN: 2249 8958, Volume-9 Issue-1 (2019)

4. M. Kavitha, P. B. Bobba and D. Prasad, 2016 IEEE 6th International Conference on Power Systems (ICPS), 2016, pp. 1-6

5. T.Srinivas and R. N. Koushik, Int. J. of Innov. Tech. and Explor. Eng.g (IJITEE), ISSN: 22783075, Volume-8 Issue-12 (2019), PP 112-117.

6. K. Sai Gopi, Dr. T. Srinivas and S. P. Raju V, E3S Web of Conferences ICMED 184, 01084GRIET, $\quad 28-29 \quad$ February, https://doi.org/10.1051/e3sconf/202018401108 $4(2020)$ 
7. Jagannadha Kumar, M.V., Jagannadha Rao, K., Dean Kumar, B., Srinivasa Reddy, V., Int. J. of Civil Eng. and Tech., 9(7), pp. 1133-1141 (2018)

8. Ganta, J.K., Seshagiri Rao, M.V., Mousavi, S.S., Srinivasa Reddy, V., Bhojaraju, C., Structures 28, pp. 956-972 (2020)

9. Naidu, K.S.S.T., Rao, M.V.S., Reddy, V.S., Int. J. of Innov. Tech. and Explor. Eng.g (IJITEE), 8(9 Special Issue 2), pp. 641-642 (2019)

10. S. Seshadri, M. Kavitha and P. B. Bobba, 2018 International Conference on Power, Instrumentation, Control and Computing (PICC), 2018, pp. 1-6

11. Chandana Priya, C., Seshagiri Rao, M.V., Srinivasa Reddy, V., Int. J. of Civil Eng. and Tech., 9(11), pp. 2218-2225 (2018)

12. Satya Sai Trimurty Naidu, K., Seshagiri Rao, M.V., Srinivasa Reddy, V., Int. J. of Civil Eng. and Tech., 9(11), pp. 2383-2393 (2018)

13. Supriya, Y., Srinivasa Reddy, V., Seshagiri Rao, M.V., Shrihari, S., Int. J. of Rec. Tech. and Engi., 8(3), pp. 5381-5385 (2019)

14. Kotkunde, N., Krishna, G., Shenoy, S.K., Gupta, A.K., Singh, S.K. International Journal of Material Forming, 10 (2), pp. 255-266 (2017)

15. Govardhan, D., Kumar, A.C.S., Murti, K.G.K., Madhusudhan Reddy, G. Materials and Design, 36, pp. 206-214. (2012)

16. D. Baloji, K. Anil, K. Satyanarayana, S. K. Singh, and M.T. Naik, Materials Today: Proceedings, 18, 4475 (2019).

17. Kumar, P., Singhal, A., Mehta, S., Mittal, A. Journal of Real-Time Image Processing, 11 (1), pp. 93-109. (2016)

18. Srinivas Rao J, S K Tummala, Kuthuri N R, Indonesia Journal of Electrical Engg. \& Computer Science, 21 (723), 2020

19. Raghunadha Reddy, T., Vishnu Vardhan, B., Vijayapal Reddy, P. International Journal of Applied Engineering Research, 11 (5), pp. 30923102 (2016)

20. Hussaini, S.M., Krishna, G., Gupta, A.K., Singh, S.K. Journal of Manufacturing Processes, 18, pp. 151-158 (2015) 